\title{
PERLINDUNGAN HAK ASASI MANUSIA ANAK TERHADAP TINDAK PIDANA KEKERASAN DALAM KAJIAN PERATURAN PERUNDANG- UNDANGAN
}

\author{
I Gede Sadia Dwi Ratmaja \\ Fakultas Hukum, Universitas Udayana \\ E-mail : igedesadiadwiratmaja@yahoo.com
}

\begin{abstract}
Abstrak
Penelitian ini bertujuan untuk mengkaji perlindungan hukum hak asasi manusia terhadap anak korban dan pelaku tindak pidana kekerasan. Jenis Penelitian yang digunakan dalam penulisan ini termasuk ke dalam penelitian hukum normatif dengan menggunakan pendekatan peraturan perundang-undangan dan pendekatan konsep. Bahan hukum yang digunakan terdiri dari bahan hukum primer, sekunder dan tersier dengan menggunakan teknik analisis deskriptif. Hasil penelitian menunjukkan bahwa perlindungan hak asasi manusia anak sebagai korban tindak pidana kekerasan telah diatur dalam berbagai peraturan perundang-undangan. Korban harus mendapat perlindungan dalam setiap proses peradilan dengan memperhatikan kepentingan anak dan mengusahakan suasana kekeluargaan, wajib didampingi, diberi kesempatan oleh hakim untuk menyampaikan pendapat, berhak atas upaya rehabilitasi, upaya perlindungan dan pemberitaan identitas untuk menghindari labelisasi, pemberian jaminan keselamatan bagi saksi korban dan saksi ahli baik fisik, mental, maupun sosial, serta pemberian aksebilitas untuk mendapatkan informasi mengenai perkembangan perkara. Selanjutnya, perlindungan hak asasi manusia anak sebagai pelaku tindak pidana kekerasan dilakukan melalui pendekatan keadilan restoratif yang merupakan penyelesaian perkara tindak pidana dengan melibatkan pelaku, korban, keluarga pelaku/korban, dan pihak lain yang terkait untuk bersama-sama mencari penyelesaian yang adil dengan menekankan pemulihan kembali pada keadaan semula, dan bukan pembalasan. Perlindungan juga diberikan melalui proses diversi dan proses peradilan yang dilewati oleh anak sebagai pelaku tindak kekerasan.
\end{abstract}

\section{Kata Kunci: Perlindungan Hukum, Anak, Kekerasan, Peraturan Perundang- Undangan}

\section{Abstract}

This research aims to examine the protection of human rights law for child victims and perpetrators of violent crime. The type of research used in this paper is included in normative legal research using the statutory approach and the concept approach. The legal material used consists of primary, secondary and tertiary legal materials using descriptive analysis techniques. The results of this research show that the protection of children's human rights as victims of violent crimes has been regulated in the law of the Republic of 
Indonesia. Victims must receive protection in every judicial process by taking into account the interests of children and fostering a family atmosphere, must be accompanied, given the opportunity by judges to express their opinions, entitled to rehabilitation efforts, protection efforts and reporting of identity to avoid labeling, providing safety guarantees for victims and witnesses both physical, mental, and social experts, as well as the provision of accessibility to obtain information on case developments. Furthermore, the protection of children's human rights as perpetrators of violent crimes is carried out through a restorative justice approach which is the settlement of criminal cases involving the perpetrators, victims, families of the perpetrators/victims, and other related parties to jointly seek a fair solution by emphasizing recovery back to its original state, and not retaliation. Protection is also provided through diversion and justice processes that are passed by children as perpetrators of violence.

Keywords: Legal Protection, Children, Violence, The Law of The Republic of Indonesia

\section{Pendahuluan}

Indonesia telah menerapkan perlindungan terhadap hak yang dimiliki oleh setiap masyarakatnya melalui Undang-Undang Nomor 39 tahun 1999 tentang Hak Asasi Manusia. Undang-undang tersebut telah mengatur dengan tegas bahwa hak-hak yang khususnya dimiliki oleh seorang anak harus dilindungi. Hal tersebut sebagaimana yang terdapat pada Pasal 1 angka 1 Undang-Undang Nomor 39 tahun 1999 tentang Hak Asasi Manusia, pada prinsipnya hak asasi manusia merupakan seperangkat hak yang melekat pada keberadaan manusia sebagai makhluk ciptaan Tuhan. Pengaturan lebih lanjut terkait dengan hak yang dimiliki oleh anak sebagaimana yang terdapat pada Pasal 52 Undang-Undang Nomor 39 tahun 1999 yang menyatakan bahwa setiap anak berhak atas perlindungan oleh orang tua, keluarga, masyarakat, dan negara. Hak anak adalah hak asasi manusia dan untuk kepentingannya, hak anak itu diakui dan dilindungi oleh hukum bahkan sejak dalam kandungan.

Anak merupakan bagian dari generasi muda dan salah satu sumber daya manusia yang merupakan potensi serta penerus citacita perjuangan bangsa. Anak memiliki peranan strategis dan mempunyai ciri dan sifat yang khusus (Mohammad Taufik Makarao, dkk., 2013:1). Perlindungan yang diberikan terhadap anak dapat diartikan sebagai upaya perlindungan hukum terhadap berbagai kebebasan dan hak asasi anak serta berbagai kepentingan yang berhubungan dengan kesejahteraan anak (Waluyadi, 2009:1). Setiap anak nantinya akan memiliki tanggung jawab, sehingga perlu mendapat kesempatan yang seluas-luasnya baik secara fisik maupun mental sosial untuk tumbuh dan berkembang secara optimal, berakhlak mulia, serta perlu 
dilakukan upaya perlindungan untuk mewujudkan kesejahteraan anak dengan memberikan jaminan terhadap pemenuhan hak-haknya.

Seseorang memiliki hak asasi manusia yaitu mulai dari saat ia dilahirkan dan berakhir pada saat ia meninggal dunia, bahkan seorang anak yang masih dalam kandungan ibunya dapat dianggap sebagai pembawa hak (C.S.T Kansil, 1989:117). Undang-Undang Nomor 23 Tahun 2002 sebagaimana yang telah dirubah dengan Undang-Undang Nomor 35 Tahun 2014 tentang Perlindungan Anak menyatakan bahwa, perlindungan anak bertujuan untuk menjamin terpenuhinya hakhak anak agar dapat hidup, tumbuh, berkembang, dan berpartisipasi secara optimal sesuai dengan harkat dan martabat kemanusiaan, serta mendapat perlindungan dari kekerasan dan diskriminasi, demi terwujudnya anak Indonesia yang berkualitas, berakhlak mulia, dan sejahtera.

Kekerasan yang melibatkan anak merupakan salah satu kasus yang sering terjadi kapanpun, dimanapun, dan hampir disetiap tempat (Romli Atmasasmita, 1995:165). Peraturan perundangundangan telah mengatur mengenai perlindungan terhadap anak dari tindakan kekerasan, eksploitasi, dan penyalahgunaan kekuasaan, namun kekerasan terhadap anak masih sering terjadi yang dipengaruhi oleh berbagai faktor-faktor tertentu, seperti lingkungan, kurangnya pendidikan atau pengetahuan agama, faktor dari dalam diri seorang anak, keluarga, psikologis, dan lain sebagainya. Kekerasan secara umum digunakan untuk menggambarkan perilaku, baik yang terbuka atau tertutup, dan baik yang bersifat menyerang atau bertahan, yang disertai penggunaan kekuatan kepada orang lain.

Kekerasan yang terjadi terhadap anak-anak tidak hanya meliputi fisik, tetapi juga psikis yang tentunya akan menimbulkan berbagai dampak negatif bagi anak-anak. Penanganan kasus kekerasan terhadap anak tidak banyak dilaporkan kepada pihak kepolisian karena pengetahuan yang kurang dari masyarakat mengenai mekanisme pelaporan, tidak cukupnya bukti-bukti yang dimiliki, perasaan takut akan diketahui oleh masyarakat, dan faktor-faktor lainnya. Anak pada hakikatnya tidak dapat melindungi diri sendiri dari berbagai tindakan-tindakan yang dapat menimbulkan kerugian dalam kehidupannya, sehingga membutuhkan perlindungan dari berbagai pihak. Perlindungan juga tidak hanya diberikan kepada anak yang menjadi korban dari tindak pidana kekerasan, tetapi juga harus diberikan kepada anak yang melakukan perbuatan menyimpang maupun perbuatan yang melanggar hukum, khususnya dalam pelaksanaan peradilan pidana anak.

Anak perlu mendapatkan perlindungan dari kesalahan penerapan peraturan perundangundangan yang diberlakukan 
terhadap dirinya yang dapat menimbulkan kerugian baik dari sisi mental, fisik, maupun sosial (Maidin Gultom, 2008:2). Untuk melaksanakan pembinaan dan memberikan perlindungan terhadap anak, diperlukan dukungan, baik yang menyangkut kelembagaan maupun perangkat hukum yang lebih mantap dan memadai, sehingga ketentuan mengenai penyelengaraan pengadilan bagi anak perlu dilakukan secara khusus (Mohammad Taufik Makarao, dkk., 2013:1).

Pemerintah kemudian telah mengesahkan undang-undang khususnya bagi anak yang melakukan tindak pidana sebagaimana yang terdapat pada Undang-Undang Nomor 11 Tahun 2012 tentang Sistem Peradilan Pidana Anak. Undang-undang tersebut menjelaskan bahwa anak memiliki peran strategis yang secara tegas dinyatakan bahwa negara menjamin hak setiap anak atas kelangsungan hidup, tumbuh, dan berkembang serta atas pelindungan dari kekerasan dan diskriminasi. Oleh karena itu, kepentingan terbaik bagi anak patut dihayati sebagai kepentingan terbaik bagi kelangsungan hidup umat manusia.

Melihat berbagai peraturan perundang-undangan yang berupaya untuk melindungi anak dari berbagai tindak kekerasan dan anak yang notabennya sebagai penerus bangsa seharusnya mendapatkan hak-hak agar dapat hidup, tumbuh, berkembang dan berpartisipasi secara optimal sesuai harkat dan martabat kemanusiaan, serta mendapat perlindungan dari kekerasan dan diskriminasi, justru sering menjadi pihak yang terlibat dalam kasus tersebut.

\section{Perumusan Masalah}

1. Bagaimana konsep mengenai kekerasan, anak, dan perlindungan hukum?

2. Bagaimana perlindungan hukum hak asasi manusia terhadap anak korban tindak pidana kekerasan?

3. Bagaimana perlindungan hukum hak asasi manusia terhadap anak pelaku tindak pidana kekerasan?

\section{Metode Penelitian}

Jenis Penelitian yang digunakan dalam penulisan ini termasuk ke dalam penelitian hukum normatif. Penelitian hukum normatif berarti penelitian hukum yang meletakkan hukum sebagai sebuah bangunan sistem norma. Penelitian ini menggunakan pendekatan peraturan perundang-undangan dengan mengkaji Undang-Undang Nomor 39 Tahun 1999 tentang Hak Asasi Manusia, Undang-Undang Nomor 11 Tahun 2012 tentang Sistem Peradilan Pidana Anak, UndangUndang Nomor 35 Tahun 2014 tentang Perlindungan Anak, dan Undang-Undang Nomor 31 Tahun 2014 tentang Perlindungan Saksi dan Korban. Penelitian ini juga menggunakan pendekatan konsep yang beranjak dari pandanganpandangan dan doktrin yang 
berkembang dalam ilmu hukum serta dimungkinkan menggunakan konsep hukum dari sistem hukum tertentu. Bahan hukum yang digunakan terdiri dari bahan hukum primer, sekunder dan tersier. Teknik analisis menggunakan teknik deskriptif yang dianalisis secara sistematis kemudian dipaparkan dalam bentuk uraianuraian yang berhubungan dengan teori yang ada, sehingga memperoleh suatu kesimpulan dan gambaran yang jelas dalam pembahasan.

\section{Kekerasan, Anak, dan Perlindungan Hukum}

Kekerasan merupakan padanan makna dari istilah violence yang secara etimologi merupakan gabungan dari vis yang mengandung makna daya atau kekuatan dan latus yang berasal dari kata ferre yang mengandung makna membawa. Berdasarkan hal tersebut maka, violence merupakan tindakan yang membawa kekuatan untuk melakukan paksaan atau tekanan fisik maupun non fisik (Maidin Gultom, 2012:14). Kekersan tidak hanya diartikan secara fisik, tetapi juga secara mental bahkan secara pasif atau tidak melakukan apapun juga dapat menghasilkan dampak yang sama dengan yang ditimbulkan kekerasan (Nyoman Mas Aryani, 2016:21).

Undang-Undang Nomor 35 Tahun 2014 tentang Perlindungan Anak, menjelaskan bahwa yang dimaksud kekerasan terhadap anak adalah diskriminasi, eksploitasi baik fisik maupun seksual, penelantaran, kekejaman, kekerasan, dan penganiayaan, ketidakadilan, dan perlakuan salah lainnya. Kekerasan terhadap anak merujuk pada perbuatan terhadap anak yang berakibat timbulnya kesengsaraan atau penderitaan secara fisik, psikis, seksual, dan/atau penelantaran, termasuk ancaman untuk melakukan perbuatan, pemaksaan, atau perampasan kemerdekaan secara melawan hukum.

Istilah kekerasan juga

berkonotasi kecendurungan agresif untuk perilaku yang merusak dan untuk menyebabkan penderitaan atau menyakiti orang lain. Kekerasan yang terjadi kepada anak dapat merusak, berbahaya dan menakutkan. Anak yang menjadi korban kekerasan menderita kerugian yang tidak saja bersifat matertial, tetapi juga bersifat immaterial seperti goncangan emosional dan psikologis, sehingga dapat mempengaruhi kehidupan masa depan anak (Renaldi P. Bahewa, 2016:21).

Pasal 1 angka 1 UndangUndang Nomor 23 tahun 2002 tentang Perlindungan anak menjelaskan bahwa, anak adalah seseorang yang belum berusia 18 (delapan belas) tahun, termasuk anak yang masih dalam kandungan. Selanjutnya, Pada Undang-Undang Nomor 11 Tahun 2012 tentang Sistem Peradilan Pidana Anak menyatakan bahwa pengertian anak diperluas lagi dan cenderung kepada penggunaan anak dalam sistem peradilan, yaitu anak yang berhadapan dengan hukum, anak yang berkonflik dengan 
hukum, anak yang menjadi korban tindak pidana, dan anak yang menjadi saksi tindak pidana.

Anak yang berhadapan dengan hukum adalah anak yang berkonflik dengan hukum, anak yang menjadi korban tindak pidana, dan anak yang menjadi saksi tindak pidana. Anak yang berkonflik dengan hukum yang selanjutnya disebut anak adalah anak yang telah berumur 12 (dua belas) tahun, tetapi belum berumur 18 (delapan belas) tahun yang diduga melakukan tindak pidana. Selanjutnya, anak yang menjadi korban tindak pidana yang selanjutnya disebut anak korban adalah anak yang belum berumur 18 (delapan belas) tahun yang mengalami penderitaan fisik, mental, dan/atau kerugian ekonomi yang disebabkan oleh tindak pidana.

Perlindungan

hukum merupakan suatu hal atau perbuatan untuk melindungi subyek hukum berdasarkan pada peraturan perundang-undangan yang berlaku disertai dengan sanksi-sanksi bila ada yang melakukan pelanggaran (Soedikno Mertokusumo, 1991:9). Perlindungan hukum lahir dari suatu ketentuan dan segala peraturan hukum yang diberikan oleh masyarakat. Pada dasarnya, kesepakatan tersebut digunakan untuk mengatur hubungan perilaku antara anggota-anggota masyarakat dan antara perseorangan dengan pemerintah yang dianggap mewakili kepentingan masyarakat (Satjipto Raharjo, 2000:53).
Perlindungan hukum merupakan penyempitan arti dari perlindungan, dalam hal ini hanya perlindungan oleh hukum saja. Perlindungan yang diberikan oleh hukum, terkait pula dengan adanya hak dan kewajiban, dalam hal ini yang dimiliki oleh manusia sebagai subyek hukum dalam interaksinya dengan sesame manusia serta lingkungannya. Sebagai subyek hukum manusia memiliki hak dan kewajiban untuk melakukan suatu tindakan hukum (C.S.T Kansil, 1989:102).

Pasal 1 ayat (8) Undang-Undang Nomor 31 Tahun 2014 tentang Perlindungan Saksi dan Korban menyebutkan bahwa perlindungan adalah segala upaya pemenuhan hak dan pemberian bantuan untuk memberikan rasa aman kepada Saksi dan/atau Korban yang wajib dilaksanakan oleh Lembaga Perlindungan Saksi dan Korban atau lembaga lainnya sesuai dengan ketentuan undang-undang. Undangundang tersebut menyatakan bahwa suatu perlindungan telah diberikan kepada setiap orang, baik orang dewasa maupun anak-anak yang menjadi saksi dan/atau korban dalam suatu tindak pidana. Selanjutnya, Pasal 1 angka 3 UndangUndang Nomor 31 Tahun 2014 tentang Perlindungan Saksi dan Korban menyebutkan bahwa korban merupakan orang yang mengalami penderitaan fisik, mental, dan/atau kerugian ekonomi yang diakibatkan oleh suatu tindak pidana. 


Jika terkait $\begin{array}{r}\text { dengan } \\ \text { anak, }\end{array}$
perlindungan terhadap
diartikan sebagai segala kegiatan
untuk menjamin dan melindungi
anak dan hak-hak anak agar dapat
hidup, tumbuh, berkembang, dan
berpartisipasi secara optimal sesuai
dengan harkat dan martabat
kemanusian serta mendapat
perlindungan dari kekerasan dan
diskriminasi (Irma Setyowati
Soemitro, 1990:47). Perlindungan
hukum bagi anak memiliki ruang
lingkup yang mencakup
perlindungan terhadap kebebasan
anak, perlindungan terhadap hak
asasi anak, dan perlindungan hukum
terhadap semua kepentingan anak
yang berkaitan dengan
kesejahteraannya (Barda Nawawi
Arief, 1998:153).

Perlindungan Hukum Hak Asasi Manusia Terhadap Anak Korban Tindak Pidana Kekerasan

Melihat dari konsepsi perlindungan anak yang utuh, menyeluruh, dan komprehensif, Undang-Undang Nomor 35 Tahun 2014 tentang Perlindungan Anak memiliki kewajiban untuk memberikan perlindungan kepada anak berdasarkan asas-asas nondiskriminasi, kepentingan yang terbaik bagi anak, hak untuk hidup, kelangsungan hidup, perkembangan, serta penghargaan terhadap pendapat anak. Perlindungan anak merupakan suatu usaha yang mengadakan situasi dan kondisi yang memungkinkan pelaksanaan hak dan kewajiban anak secara manusiawi.
Pasal 58 Undang-Undang Nomor 39 tahun 1999 tentang Hak Asasi Manusia menyebutkan perlindungan yang diberikan kepada anak bahwa, setiap anak berhak untuk mendapatkan perlindungan hukum dari segala bentuk kekerasan fisik atau mental, penelantaran, perlakuan buruk, dan pelecehan seksual selama dalam pengasuhan orang tua atau walinya, atau pihak lain manapun yang bertanggungjawab atas pengasuhan. Dalam hal orang tua, wali, atau pengasuh anak melakukan segala bentuk penganiayaan fisik atau mental, penelantaran, perlakuan buruk, dan pelecehan seksual termasuk pemerkosaan, dan atau pembunuhan terhadap anak yang seharusnya dilindungi maka harus dikenakan pemberatan hukuman.

Perlindungan hukum terhadap anak korban kekerasan dapat dilakukan secara langsung dan tidak langsung. Perlindungan secara langsung dimaksudkan bahwa kegiatan dilakukan dengan ditujukan kepada anak yang menjadi sasaran penanganan langsung. Kegiatan yang dilakukan dengan cara melindungi anak dari berbagai ancaman dari luar dan dalam dirinya, mendidik, mendampingi anak, membina, mengusahakan kesehatanya, menyediakan sarana pengembangan diri, dan lain sebagainya. Selanjutnya, perlindungan anak secara tidak langsung dilakukan dengan kegiatan yang tidak langsung ditujukan kepada anak, tetapi orang lain yang melakukan/terlibat dalam usaha 
perlindungan anak. Usaha perlindungan anak yang demikian misalnya dilakukan oleh orang tua atau orang yang terlibat dalam usahausaha perlindungan anak terhadap berbagai ancaman dari luar ataupun dari dalam diri anak seperti membina, mengasuh, mendampingi anak dengan berbagai cara.

Pasal 64 ayat (3) UndangUndang Nomor 35 Tahun 2014 tentang Perlindungan Anak telah menyebutkan bahwa anak sebagai korban mendapatkan rehabilitasi baik dalam lembaga maupun luar lembaga, upaya perlindungan dan pemberitaan identitas melalui media massa untuk menghindari labelisasi, pemberian jaminan keselamatan bagi saksi korban dan saksi ahli baik fisik, mental, maupun sosial, serta pemberian aksebilitas untuk mendapatkan informasi mengenai perkembangan perkara (Rena Yulia, 2010:196).

Perlindungan bagi anak korban tindak kekerasan diatur juga sebagaimana yang terdapat pada Pasal 5 Undang-Undang Nomor 31 Tahun 2014 tentang Perlindungan Saksi dan Korban, menyebutkan bahwa korban berhak untuk:

a. memperoleh perlindungan atas keamanan pribadi, Keluarga, dan harta bendanya, serta bebas dari Ancaman yang berkenaan dengan kesaksian yang akan, sedang, atau telah diberikannya;

b. ikut serta dalam proses memilih dan menentukan bentuk perlindungan dan dukungan keamanan; c. memberikan keterangan tanpa tekanan;

d. mendapat penerjemah;

e. bebas dari pertanyaan yang menjerat;

f. mendapat informasi mengenai perkembangan kasus;

g. mendapat informasi mengenai putusan pengadilan;

h. mendapat informasi dalam hal terpidana dibebaskan;

i. dirahasiakan identitasnya;

j. mendapat identitas baru;

k. mendapat tempat kediaman sementara;

1. mendapat tempat kediaman baru;

m. memperoleh penggantian biaya transportasi sesuai dengan kebutuhan;

n. mendapat nasihat hukum;

o. memperoleh bantuan biaya hidup sementara sampai batas waktu Perlindungan berakhir; dan/atau

p. mendapat pendampingan.

Korban pelanggaran hak asasi manusia yang berat, Korban tindak pidana terorisme, Korban tindak pidana perdagangan orang, Korban tindak pidana penyiksaan, Korban tindak pidana kekerasan seksual, dan Korban penganiayaan berat, berhak juga untuk mendapatkan bantuan medis dan bantuan rehabilitasi psikososial serta psikologis yang diberikan berdasarkan Keputusan Lembaga Perlindungan Saksi dan Korban. Bantuan medis merupakan bantuan yang diberikan untuk memulihkan kesehatan fisik Korban, termasuk melakukan pengurusan 
dalam hal Korban meninggal dunia misalnya pengurusan jenazah hingga pemakaman.

Rehabilitasi psikososial merupakan semua bentuk pelayanan dan bantuan psikologis serta sosial yang ditujukan untuk membantu meringankan, melindungi, dan memulihkan kondisi fisik, psikologis, sosial, dan spiritual Korban sehingga mampu menjalankan fungsi sosialnya kembali secara wajar, antara lain Lembaga Perlindungan Saksi dan Korban berupaya melakukan peningkatan kualitas hidup Korban dengan melakukan kerja sama dengan instansi terkait yang berwenang berupa bantuan pemenuhan sandang, pangan, papan, bantuan memperoleh pekerjaan, atau bantuan kelangsungan pendidikan. Selanjutnya, rehabilitasi psikologis merupakan bantuan yang diberikan oleh psikolog kepada Korban yang menderita trauma atau masalah kejiwaan lainnya untuk memulihkan kembali kondisi kejiwaan Korban.

Perlindungan yang diberikan bagi anak korban tindak pidana kekerasan dalam proses peradilan bahwa, pembimbing kemasyarakatan, pekerja sosial profesional dan tenaga kesejahteraan sosial, penyidik, penuntut umum, hakim, dan advokat atau pemberi bantuan hukum lainnya wajib memperhatikan kepentingan terbaik bagi anak dan mengusahakan suasana kekeluargaan tetap terpelihara. Identitas anak korban wajib untuk dirahasiakan dalam pemberitaan di media cetak ataupun elektronik. Dalam setiap tingkat pemeriksaan, anak korban wajib didampingi oleh orang tua dan/atau orang yang dipercaya oleh anak korban atau pekerja sosial. Penyidik wajib meminta laporan sosial dari pekerja sosial profesional atau tenaga kesejahteraan sosial setelah tindak pidana dilaporkan atau diadukan dalam hal melakukan pemeriksaan terhadap anak korban tindak kekerasan.

Pasal $58 \quad$ Undang-Undang Nomor 11 Tahun 2012 tentang Sistem Peradilan Pidana Anak menyebutkan bahwa, pada saat memeriksa anak korban tindak kekerasan, hakim dapat memerintahkan agar pelaku dibawa keluar ruang sidang. Pada saat pemeriksaan tersebut, orang tua/wali, advokat atau pemberi bantuan hukum lainnya, dan pembimbing kemasyarakatan tetap hadir. Dalam hal anak korban tidak dapat hadir untuk memberikan keterangan di depan sidang pengadilan, hakim dapat memerintahkan anak korban didengar keterangannya di luar sidang pengadilan melalui perekaman elektronik yang dilakukan oleh pembimbing kemasyarakatan di daerah hukum setempat dengan dihadiri oleh penyidik atau penuntut umum dan advokat atau pemberi bantuan hukum lainnya. Selanjutnya dapat juga melalui pemeriksaan langsung jarak jauh dengan alat komunikasi audiovisual dengan didampingi oleh orang tua/wali, pembimbing kemasyarakatan atau pendamping lainnya. Dalam hal tertentu anak korban diberi 
kesempatan oleh hakim untuk menyampaikan pendapat tentang perkara yang bersangkutan.

Pasal 91 Undang-Undang Nomor 11 Tahun 2012 tentang Sistem Peradilan Pidana Anak menyebutkan bahwa, anak korban tindak kekerasan juga memiliki hak atas perlindungan sebagaimana diatur dalam peraturan perundang-undangan serta berhak atas upaya rehabilitasi medis dan rehabilitasi sosial, baik di dalam lembaga maupun di luar lembaga. Selain itu, berhak atas jaminan keselamatan, baik fisik, mental, maupun sosial, serta berhak atas kemudahan dalam mendapatkan informasi mengenai perkembangan perkara. Berdasarkan pertimbangan atau saran pembimbing kemasyarakatan, pekerja sosial profesional atau tenaga kesejahteraan sosial atau penyidik dapat merujuk anak korban ke instansi atau lembaga yang menangani perlindungan anak atau lembaga kesejahteraan sosial anak.

Dalam hal anak korban memerlukan tindakan pertolongan segera, penyidik, tanpa laporan sosial dari pekerja sosial profesional, dapat langsung merujuk anak korban ke rumah sakit atau lembaga yang menangani perlindungan anak sesuai dengan kondisi anak korban. Anak korban tindak kekerasan yang memerlukan perlindungan dapat memperoleh perlindungan dari lembaga yang menangani perlindungan saksi dan korban atau rumah perlindungan sosial sesuai dengan ketentuan peraturan perundang-undangan.

Perlindungan Hukum Hak Asasi Manusia Terhadap Anak Pelaku Tindak Pidana Kekerasan

Proses peradilan terhadap anak seringkali kehilangan makna esensinya, yaitu sebagai mekanisme yang harus berakhir dengan upaya untuk melindungi kepentingan terbaik bagi anak. Peradilan pidana anak sering menjadi proses yang hanya berorientasi pada penegakan hukum secara formal dan tidak berorientasi pada kepentingan anak (Achmad Ratomi, 2013:395). UndangUndang Nomor 11 Tahun 2012 tentang Sistem Peradilan Pidana Anak bertujuan untuk menjaga harkat dan martabat anak dengan pendekatan keadilan restoratif, seorang anak berhak mendapatkan perlindungan khusus, terutama pelindungan hukum dalam sistem peradilan pidana. Pasal 1 angka 6 Undang-Undang Nomor 11 Tahun 2012 tentang Sistem Peradilan Pidana Anak menjelaskan keadilan restoratif adalah penyelesaian perkara tindak pidana dengan melibatkan pelaku, korban, keluarga pelaku/korban, dan pihak lain yang terkait untuk bersama-sama mencari penyelesaian yang adil dengan menekankan pemulihan kembali pada keadaan semula, dan bukan pembalasan.

Berdasarkan hal tersebut maka, sistem peradilan pidana anak tidak hanya ditekankan pada penjatuhan sanksi pidana bagi anak pelaku tindak pidana, namun difokuskan 
juga pada pemikiran bahwa penjatuhan sanksi dimaksudkan sebagai sarana mewujudkan kesejahteraan anak pelaku tindak pidana. Perlindungan terhadap anak sebagai pelaku tindak pidana kekerasan telah diatur sebagaimana yang terdapat pada Pasal 64 ayat (3) Undang-Undang Nomor 35 Tahun 2014 tentang Perlindungan Anak telah menyebutkan bahwa perlindungan khusus bagi anak yang berhadapan dengan hukum dilakukan melalui :

a. perlakuan secara manusiawi dengan memperhatikan kebutuhan sesuai dengan umurnya;

b. pemisahan dari orang dewasa;

c. pemberian bantuan hukum dan bantuan lain secara efektif;

d. pemberlakuan kegiatan rekreasional;

e. pembebasan dari penyiksaan, penghukuman, atau perlakuan lain yang kejam, tidak manusiawi serta merendahkan martabat dan derajatnya;

f. penghindaran dari penjatuhan pidana mati dan/atau pidana seumur hidup;

g. penghindaran dari penangkapan, penahanan atau penjara, kecuali sebagai upaya terakhir dan dalam waktu yang paling singkat;

h. pemberian keadilan di muka pengadilan Anak yang objektif, tidak memihak, dan dalam sidang yang tertutup untuk umum; i. penghindaran dari publikasi atas identitasnya;

j. pemberian pendampingan Orang Tua/Wali dan orang yang dipercaya oleh Anak;

k. pemberian advokasi sosial;

1. pemberian kehidupan pribadi;

m. pemberian aksesibilitas, terutama bagi Anak Penyandang Disabilitas;

n. pemberian pendidikan;

o. pemberian pelayanan kesehatan; dan

p. pemberian hak lain sesuai dengan ketentuan peraturan perundang-undangan.

Perlindungan hukum yang diberikan kepada anak pelaku tindak kekerasan menurut Undang-Undang Nomor 11 Tahun 2012 tentang Sistem Peradilan Pidana Anak dilakukan melalui proses diversi. Pelaksanaan diversi oleh aparat penegak hukum didasari oleh kewenangan diskresi yang dimiliki aparat penegak hukum. Penerapan konsep diversi bentuk peradilan formal lebih mengutamakan usaha memberikan perlindungan bagi anak dari tindakan pemenjaraan. Diversi dilakukan untuk memberikan perlindungan dan rehabilitasi kepada pelaku sebagai upaya untuk mencegah anak menjadi pelaku kriminal dewasa (Yati Sharfina Desiandri, dkk., 2017:150).

Diversi bertujuan untuk mencapai perdamaian antara korban dan anak pelaku tindak kekerasan, menyelesaikan perkara anak di luar proses peradilan, menghindarkan anak dari perampasan kemerdekaan, mendorong masyarakat untuk 
berpartisipasi, dan menanamkan rasa tanggung jawab kepada anak sebagai pelaku tindak kekerasan. Anak sebagai pelaku tindak pidana kekerasan juga mendapatkan perlindungan terkait dengan hak-hak yang dimiliki sebagaimana diatur pada Pasal 3 Undang-Undang Nomor 11 Tahun 2012 tentang Sistem Peradilan Pidana Anak yang menyebutkan bahwa setiap anak dalam proses peradilan pidana berhak:

a. diperlakukan secara manusiawi dengan memperhatikan kebutuhan sesuai dengan umurnya;

b. dipisahkan dari orang dewasa;

c. memperoleh bantuan hukum dan bantuan lain secara efektif;

d. melakukan kegiatan rekreasional;

e. bebas dari penyiksaan, penghukuman atau perlakuan lain yang kejam, tidak manusiawi, serta merendahkan derajat dan martabatnya;

f. tidak dijatuhi pidana mati atau pidana seumur hidup;

g. tidak ditangkap, ditahan, atau dipenjara, kecuali sebagai upaya terakhir dan dalam waktu yang paling singkat;

h. memperoleh keadilan di muka pengadilan Anak yang objektif, tidak memihak, dan dalam sidang yang tertutup untuk umum;

i. tidak dipublikasikan identitasnya; j. memperoleh pendampingan orang tua/Wali dan orang yang dipercaya oleh Anak;

k. memperoleh advokasi sosial;

1. memperoleh kehidupan pribadi;

m. memperoleh aksesibilitas, terutama bagi anak cacat;

n. memperoleh pendidikan;

o. memperoleh pelayananan kesehatan; dan

p. memperoleh hak lain sesuai dengan ketentuan peraturan perundang-undangan

Diversi dilakukan pada tingkat penyidikan, penuntutan, dan pemeriksaan perkara anak di pengadilan negeri. Diversi dilaksanakan dalam hal tindak pidana yang dilakukan diancam dengan pidana penjara di bawah 7 (tujuh) tahun dan bukan merupakan pengulangan tindak pidana. Proses diversi dilakukan melalui musyawarah dengan melibatkan anak sebagai pelau dan orang tua/walinya, korban dan/atau orang tua/walinya, pembimbing kemasyarakatan, dan pekerja sosial profesional berdasarkan pendekatan keadilan restoratif.

Pasal 9 Undang-Undang Nomor 11 Tahun 2012 tentang Sistem Peradilan Pidana Anak menyebutkan bahwa, proses diversi wajib memperhatikan kepentingan korban, kesejahteraan dan tanggung jawab anak sebagai pelau, penghindaran stigma negative, penghindaran pembalasan, keharmonisan masyarakat, dan kepatutan, kesusilaan, dan ketertiban umum. Penyidik, Penuntut Umum, dan 
Hakim dalam melakukan diversi harus mempertimbangkan kategori tindak pidana, umur anak, hasil penelitian kemasyarakatan dari Bapas dan dukungan lingkungan keluarga dan masyarakat. Kesepakatan diversi harus mendapatkan persetujuan korban dan/atau keluarga anak korban serta kesediaan anak dan keluarganya, kecuali untuk tindak pidana yang berupa pelanggaran, tindak pidana ringan, tindak pidana tanpa korban, atau nilai kerugian korban tidak lebih dari nilai upah minimum provinsi setempat.

Proses peradilan pidana anak akan dilanjutkan dalam hal proses diversi tidak menghasilkan kesepakatan atau kesepakatan diversi tidak dilaksanakan. Perlindungan terhadap anak sebagai pelaku tindak pidana kekerasan tetap akan diberikan dalam proses peradilan. Pasal 18 Undang-Undang Nomor 11 Tahun 2012 tentang Sistem Peradilan Pidana Anak menyebutkan bahwa, dalam menangani perkara anak sebagai pelaku, maka Pembimbing Kemasyarakatan, Pekerja Sosial Profesional dan Tenaga Kesejahteraan Sosial, Penyidik, Penuntut Umum, Hakim, dan Advokat atau pemberi bantuan hukum lainnya wajib memperhatikan kepentingan terbaik bagi anak dan mengusahakan suasana kekeluargaan tetap terpelihara. Identitas anak wajib dirahasiakan dalam pemberitaan di media cetak ataupun elektronik.

Dalam setiap tingkat pemeriksaan, anak wajib diberikan bantuan hukum dan didampingi oleh
Pembimbing Kemasyarakatan atau pendamping lain sesuai dengan ketentuan peraturan perundangundangan. Terkait dengan proses penyidikan terhadap perkara anak, maka Penyidik wajib meminta pertimbangan atau saran dari Pembimbing Kemasyarakatan setelah tindak pidana dilaporkan atau diadukan. Penangkapan terhadap anak dilakukan guna kepentingan penyidikan paling lama 24 (dua puluh empat) jam. Anak yang ditangkap wajib ditempatkan dalam ruang pelayanan khusus Anak. Penangkapan terhadap Anak wajib dilakukan secara manusiawi dengan memperhatikan kebutuhan sesuai dengan umurnya.

\section{Kesimpulan}

1. Kekerasan terhadap anak adalah diskriminasi, eksploitasi baik fisik maupun seksual, penelantaran, kekejaman, kekerasan, dan penganiayaan, ketidakadilan, dan perlakuan salah lainnya Perlindungan terhadap anak, diartikan sebagai segala kegiatan untuk menjamin dan melindungi anak dan hak-hak anak agar dapat hidup, tumbuh, berkembang, dan berpartisipasi secara optimal sesuai dengan harkat dan martabat kemanusiaan serta mendapat perlindungan dari kekerasan dan diskriminasi.

2. Perlindungan hak asasi manusia anak sebagai korban tindak pidana kekerasan telah diatur dalam berbagai peraturan perundang-undangan. Anak 
sebagai korban harus mendapat perlindungan secara menyeluruh dalam setiap proses peradilan wajib memperhatikan kepentingan terbaik bagi anak dan mengusahakan suasana kekeluargaan tetap terpelihara, wajib didampingi oleh orang tua dan/atau orang yang dipercaya oleh anak korban atau pekerja sosial, diberi kesempatan oleh hakim untuk menyampaikan pendapat tentang perkara yang bersangkutan, memiliki hak atas perlindungan sebagaimana diatur dalam peraturan perundangundangan serta berhak atas upaya rehabilitasi baik dalam lembaga maupun luar lembaga, upaya perlindungan dan pemberitaan identitas melalui media massa untuk menghindari labelisasi, pemberian jaminan keselamatan bagi saksi korban dan saksi ahli baik fisik, mental, maupun sosial, serta pemberian aksebilitas untuk mendapatkan informasi mengenai perkembangan perkara.

3. Perlindungan hak asasi manusia anak sebagai pelaku tindak pidana kekerasan dilakukan melalui pendekatan keadilan restoratif yang merupakan penyelesaian perkara tindak pidana dengan melibatkan pelaku, korban, keluarga pelaku/korban, dan pihak lain yang terkait untuk bersama-sama mencari penyelesaian yang adil dengan menekankan pemulihan kembali pada keadaan semula, dan bukan pembalasan. Perlindungan juga diberikan melalui proses diversi untuk mencapai perdamaian antara korban dan anak pelaku tindak kekerasan, menyelesaikan perkara anak di luar proses peradilan, menghindarkan anak dari perampasan kemerdekaan, mendorong masyarakat untuk berpartisipasi, dan menanamkan rasa tanggung jawab kepada anak sebagai pelaku tindak kekerasan. Meskipun proses diversi gagal untuk mencapai kesepakatan, perlindungan hak asasi manusia tetap diberikan dalam setiap proses peradilan yang dilewati oleh anak sebagai pelaku tindak kekerasan.

\section{Rekomendasi}

1. Aparat penegak hukum dalam melaksanakan tugas baik penyidikan, penuntutan, pemeriksaan dan penentuan putusan perkara pada sidang pengadilan hendaknya tetap memberikan perlindungan hak asasi manusia kepada anak sebagai korban tindak pidana kekerasan dengan memberikan apa yang menjadi haknya sesuai dengan peraturan perundangundangan yang berlaku. Selain itu, perlindungan juga harus diberikan kepada pelaku tindak pidana kekerasan yang dilakukan melalui pendekatan keadilan restoratif dan mengutamakan pelaksanaan diversi sebagai salah satu alternatif dari pelaksanaan pidana penjara. 
2. Pemerintah, masyarakat, keluarga dan orangtua harus turut serta dalam upaya memberikan perlindungan terhadap anak dengan memenuhi hak-hak anak, melindungi kepentingan anak, serta melakukan pengawasan terhadap lingkungan anak agar tidak melakukan perbuatan yang bertentangan dengan peraturan perundang-undangan, norma, dan kesusilaan.

\section{Daftar Pustaka}

\section{Buku}

Atmasasmita, Romli, 1995, Peradilan Anak di Indonesia, Mandar Maju, Bandung.

Arief, Barda Nawawi, 1998, Beberapa Aspek Kebijakan dan Pengembangan Hukum Pidana, Citra Aditya Bakti, Bandung.

Gultom, Maidi, 2008, Perlindungan Hukum terhadap Anak dalam Sistem Peradilan Anak di Indonesia, Rafika Aditama, Bandung

, Maidin, 2012, Perlindungan Hukum Terhadap Anak dan Perempuan, Refika Aditama, Bandung.

Kansil, C.S.T., 1989, Pengantar Ilmu Hukum Dan Tata Hukum Indonesia, Balai Pustaka, Jakarta.

Mertokusumo, Soedikno, 1991, Mengenal hukum (Suatu Pengantar), Liberty, Yogyakarta.

Makarao, Mohammad Taufik, dkk., 2013, Hukum Perlindungan Anak dan Penghapusan Kekrasan dalam
Rumah Tangga, Rineka Cipta, Jakarta.

Raharjo, Satjipto, 2000, Ilmu Hukum, Citra Aditya Bakti, Bandung.

Soemitro, Irma Setyowati, 1990, Aspek

Hukum Perlindungan Anak, Bumi Aksara, Jakarta.

Waluyadi, 2009, Hukum Perlindungan Anak, Mandar Maju, Bandung. Yulia, Rena, 2010, Viktimologi Perlindungan Hukum Terhadap Korban Kejahatan, Graha Ilmu, Bandung.

\section{Peraturan Perundang-Undangan}

Undang-Undang Republik Indonesia Nomor 39 Tahun 1999 Tentang Hak Asasi Manusia. Lembaran Negara Republik Indonesiatahun 1999 Nomor 165. Tambahan Lembaran Negara Republik Indonesia Nomor 3886.

Undang-Undang Republik Indonesia Nomor 11 Tahun 2012 Tentang Sistem Peradilan Pidana Anak. Lembaran Negara Republik Indonesia Tahun 2012 Nomor 153. Tambahan Lembaran Negara Republik Indonesia Nomor 5332

Undang-Undang Republik Indonesia Nomor 35 Tahun 2014 Tentang Perubahan Atas UndangUndang Nomor 23 Tahun 2002 Tentang Perlindungan Anak. Lembaran Negara Republik Indonesia Tahun 2014 Nomor 297. Tambahan Lembaran Negara Republik Indonesia Nomor 5606. 
Undang-Undang Republik Indonesia Nomor 31 Tahun 2014 Tentang Perubahan Atas UndangUndang Nomor 13 Tahun 2006 Tentang Perlindungan Saksi Dan Korban. Lembaran Negara Republik Indonesia Tahun 2014 Nomor 293. Tambahan Lembaran Negara Republik Indonesia Nomor 5602.

Jurnal

Aryani, Nyoman Mas, Perlindungan Hukum Terhadap Anak Sebagai Korban Kekerasan Seksual Di Provinsi Bali, Kertha Patrika, Vol. 38 No. 1, 18-30, April 2016. Bahewa, Renaldi P, Perlindungan Hukum Terhadap Anak Sebagai Korban Pelecehan Seksual Menurut Hukum Positif Indonesia, Lex Administratum, Vol. IV No. 4, 21-28, April 2016.

Desiandri, Yati Sharfina, dkk, Diversi Terhadap Anak yang Berkonflik dengan Hukum di Tingkat Penyidikan, USU Law Journal, Vol. 5 No. 1, 147-157, januari 2017.

Ratomi, Achmad, Konsep Prosedur Pelaksanaan Diversi Pada Tahap Penyidikan Dalam Penyelesaian Tindak Pidana Yang dilakukan oleh anak, Jurnal Arena Hukum, Vol. 6 No. 3, 394-407, Desember 2013. 